\title{
C.L. de Wet
}

\section{THE PUNISHMENT OF SLAVES IN EARLY CHRISTIANITY: THE VIEWS OF SOME SELECTED CHURCH FATHERS}

\section{ABSTRACT}

With few exceptions, many of the Church Fathers approved, in principle, of the punishment of slaves. However, there were very specific guidelines on why, how, and when to punish slaves. The purpose of this article is to analyse more closely how some of the early Church Fathers conceptualised the punishment of slaves. The study begins, first, by examining the theological justifications for the punishment of slaves. Secondly, it assesses the reasons for punishment - for what reasons did these Church Fathers admonish their slaveholding audiences to punish their slaves? Thirdly, the author investigates some selected Church Fathers' advice on how to punish, in terms of both the psychological disposition of the owner and the various methods for punishment directed towards the slave body. Finally, the article more specifically explores how these Church Fathers understood some of the main elements that were present in, during, and after punishment, namely fear and pain.

\section{INTRODUCTION}

"So, to discipline and punish ignorant slaves is a great accolade, and not a perchance commendation," the fourth-century Church Father John Chrysostom (Hab. eun. spir. 3.7 [PG 51.287.4-8]) exclaims, "when one can drive out wickedness using domestic violence against those who are

Prof. Chris L. de Wet, Department of Biblical and Ancient Studies, University of South Africa. Email: dwetc/@unisa.ac.za 
the most evil."1 Chrysostom's close contemporary, Augustine (Enarrat. Ps. 102.14 [CCSL 40.1464-1465]), noted that, "if you see your slave living badly, how else will you punish him if not by the whip?" Augustine then provides a simple answer to this question: "You must use the whip, use it! God allows it. Rather, he is angered if you do not lash the slave. But do it in a loving and not a cruel spirit." Both these most famous and influential Church Fathers, from the East and the West, agree that God not only approves of punishing slaves, but also commands it. By now, it has become common knowledge in scholarship on Early Christianity that the Early Church never formally abolished slavery, with the exception of Gregory of Nyssa's damning evaluation of slavery as an insult to God (cf. Hom. Eccl. 4.1-2 [SC 416.224-228]).

Some alternative Christian groups, labelled heretics by the mainstream church, namely the Marcionites (cf. Tertullian, Marc. 1.23.7 [CCSL 1.466]) and the Eustathians (who were condemned at the Council of Gangra), may have dissolved all social distinctions between slaves and masters, and, interestingly, between men and women (Glancy 2006:90; 2010a:63-80). Unfortunately, knowledge of these groups is obtained from the writings of their opponents, and one is not sure to what extent the "accusations" against them are accurate, or what the reasons were for abolishing traditional social hierarchies. Tertullian (Marc. 1.23.7 [CCSL 1.466]) was so disgusted with the Marcionites that he hesitated to call them kidnappers, since:

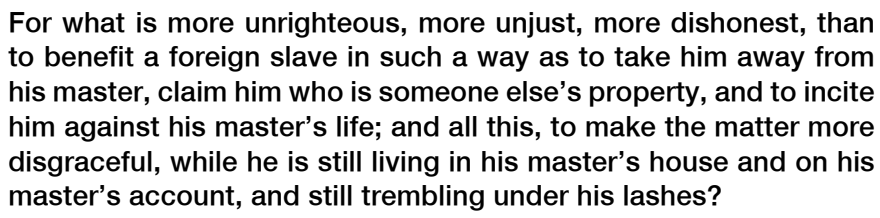

In this instance, Tertullian is concerned with the Marcionites' apparent liberation of slaves who are still "trembling under the lashes" of their masters. To Tertullian, this "liberation" is no different to stealing someone else's property (cf. also Harrill 2006:385-390).

At the start of this study, it is thus important to note that, generally, many Church Fathers approved, in principle, of the punishment of slaves. However, there were very specific guidelines on why, how, and when to punish slaves. The purpose of this article is to analyse more closely how these early Church Fathers conceptualised the punishment of slaves.

1 All translations of ancient works are my own, unless otherwise indicated. Abbreviations of ancient works follow the conventions of the SBL Handbook of Style (Collins et al. 2014; $2^{\text {nd }}$ ed.). 
I shall begin, first, by examining the theological justifications for the punishment of slaves. Secondly, I shall assess the reasons for punishment - for what reasons did these Church Fathers admonish their slaveholding audiences to punish their slaves? Thirdly, I shall investigate how these Church Fathers advised punishment, in terms of both the psychological disposition of the owner and the various methods for punishment directed towards the slave body. Finally, I shall more specifically explore how these select Church Fathers understood some of the main elements that were present in, during, and after punishment, namely fear and pain.

\section{THEOLOGICAL JUSTIFICATION FOR THE PUNISHMENT OF SLAVES}

How did the Church justify the punishment of slaves? The most important principle to take note of, in this instance, is the relationship between slavery and sin in early Christian thinking. Davis (1988:84) rightly states:

[A]s early Christians repeatedly conceived of sin and salvation in terms of slavery and freedom, the words acquired complex layers of meaning that necessarily affected men's response to the institution of slavery.

The majority of early Christian authors believed that slavery was the consequence of sin. This was an important move in understanding slavery as an institution. Many of the Church Fathers did not, for instance, understand slavery as a consequence of nature - Aristotle's concept of natural slavery may have prevailed in some schools of thought in late antiquity, but the vast majority of Church Fathers, and Roman writers, more generally, did not accept Aristotle's views on slavery. ${ }^{2}$ The attribution of slavery to sin made slavery an unnatural phenomenon in the imaginaire of many early Christians (De Wet 2010:26-39).

In De civitate Dei 19.15 (CCSL 48.682-683), ${ }^{3}$ Augustine makes it clear that slavery is the result of sin, and not nature. He explains: "[S]lavery is the result of sin. And this is why we do not find the word slave in any part of Scripture until righteous Noah branded the sin of his son with this name." Augustine then contrasts sin and nature with regard to slavery: "It is a name, therefore, introduced by sin and not by nature." Augustine also provides an interesting etymology of the Latin word for slave:

2 For a general overview of the characteristics and development of Aristotle's notion of natural slavery, cf. Ambler (1987:390-410); Garver (1994:173-15); Heath (2008:243-270).

3 Translation: NPNF. 
The origin of the Latin word for slave (seruorum) is supposed to be found in the circumstance that those who by the law of war were liable to be killed were sometimes preserved (seruabantur) by their victors, and were hence called servants (seruando). And these circumstances could never have arisen save through sin.

For Augustine, the original channels whereby the slave supply was sustained, namely through prisoners of war, is a testament to the relation between $\sin$ and slavery. ${ }^{4}$ This is then also the reason, for Augustine, why slaves should be treated with strict discipline and punished when necessary (Clark 1998:109-129). It should, however, be noted that, during Augustine's time, the slave trade was primarily sustained by means of local reproduction of slaves - i.e. breeding (Harper 2011:67-99).

Consonant views were expressed in the East. Basil of Caesarea had a similar opinion to Augustine. In De Spiritu Sancto 20.51 (SC 17.204-206), Basil writes that "among people no one is a slave by nature. For they are either brought under a yoke of slavery by conquest, as when prisoners are taken in war; or they are enslaved because of poverty".

Like Augustine, Basil cannot accept that slavery is natural when people become slaves as a result of war or poverty. But in the same section, Basil also notes:

[B]y a wise and mysterious dispensation, the worst children are by their fathers' order condemned to serve the wiser and the better; and this any righteous enquirer into the circumstances would declare to be not a sentence of condemnation but a benefit. For it is more profitable that the person who, through lack of intelligence, has no natural principle of rule within themselves, should become the chattel of another, to the end that, being guided by the reason of the master, they may be like a chariot with a charioteer, or a boat with a steersman seated at the tiller.

Although Basil does mention that slavery is not natural, he does seem to believe that some people are naturally (but perhaps meaning "socially") inclined to require domination. This sounds very similar to Aristotle's view of natural slavery, and one cannot rule out some Aristotelian influence. The background to this statement, however, may be different, and it is possible that Basil, like Augustine, is also alluding to the so-called curse of Ham (Canaan; cf. Gen. 9:21-25), in which the disobedience of Noah's son Ham resulted in his servitude. Disobedience, which was considered the foundation of sin, thus caused slavery, since disobedient persons were unable to control or rule themselves.

4 For more on Augustine's views on slavery, cf. Klein (1988). 
This very same reasoning is also found with Chrysostom. In his De inani gloria 71 (SC 188.172), Chrysostom told fathers to teach their sons the ways of free men, especially the following principle:

\begin{abstract}
Teach him the principles of the natural order, and what is a slave, and what is a free man. Say to him: My child, there were no slaves in the olden days of our forefathers, but sin led to slavery. For when someone gave insult to his father, he suffered this judgement, to become the slave of his brothers. Take heed that you do not become the slave of your slaves. If you should become angry with them and your behaviour is the same as theirs, if you should have no more virtue than them, you will have the same measure of worth as them. Endeavour then to be the master of your slaves and become so, not by behaving like a slave, but by your habits, so that while you are a freeborn man, you may never be found to be a slave of your slaves.
\end{abstract}

The "natural order" (literally, $\tau \dot{\alpha} \pi \varepsilon \rho \grave{i} \tau \tilde{\eta} \varsigma \phi u ́ \sigma \varepsilon \omega \varsigma)$ in this section does not refer to natural slavery, as Chrysostom also refuted natural slavery (De Wet 2015:70-112), but it points to the widely accepted social hierarchies of ancient everyday life. This may also be the sense that Basil implies. The difference between slave and free should be taught to the boy. Chrysostom also believed that slavery started when sons no longer honoured their fathers, and fell into disobedience. In this instance, as with Basil and Augustine, Chrysostom refers to the curse of Ham. Just like Eve was the cause of all women being subjugated to men, Ham was the cause of slavery. Chrysostom (Serm. Gen. 5.1 [SC 433.253]) states that a slave might ask, "Why on earth was it that, when Ham was insolent to his father, the effects of sin were transmitted to the whole race?" 5 He then retorts by saying that current slaves are enslaved due to their own sins. Chrysostom (Hom. Phlm. 3.2 [Field 6.352]) asks: "[l]s it not a sign of goodness to punish, and of cruelty not to punish, and is it not so in the case of God?", and then concludes: "Since God is good, he has therefore prepared a hell". Since God punishes disobedience, slaveholders also need to punish their slaves. The development of eschatological punishment and the notion of hell are indebted to the early Christians' theological use of slavery language. The anonymous fourth-century author, known colloquially as Ambrosiaster (Comm. Col. 4.1 [CSEL 81.3.202]), also states: "In God's eyes, however, a slave is a person who has sinned. Ham became a slave as a result of his sin."

Thus, the punishment (and reward, in fact) of slaves is theologically justified by the principle of divine punishment (and reward). Slaveholders

5 Translation: Hill (2004:80). For more on the curse of Ham and slavery, cf. Haynes (2002); Goldenberg (2003). 
imitate God when they punish or reward their slaves. Disobedience and sin must be punished, whether it is by God or by the slaveholder. This theological justification was achieved in contrast to Aristotle's notion of natural slavery, and was especially dependent on the scriptural narratives of the Fall and the curse of Ham.

\section{REASONS FOR PUNISHING SLAVES}

The most important reason for punishing slaves was to teach them virtue and to behave in an appropriate manner (De Wet 2015:169-195). The fear other slaves had that resulted from punishment had the added benefit of ensuring continuing good behaviour. Lactantius (Ir. 5.12 [SC 289.108]) lists the numerous measures a master had at his disposal in punishing a slave: "As for the bad slave, he [the master] brings the whole range of punishments to bear on him: curses, lashings, nakedness, hunger, thirst, chains.", and the reason for these extreme measures of punishment:

He will thus give the rest of the slaves an incentive not to misbehave, and the bad slave to behave well. Fear will restrain some of them, while others will be encouraged by the desire for honour. ${ }^{6}$

Lactantius was much more concerned with the just treatment of slaves (thus, punishing those who deserve it) and the control of the master's anger. These principles were extremely common among both the Stoics and the Church Fathers of late antiquity.

The Church Fathers expected slaves to exhibit modest, even chaste, behaviour, despite the common Roman view that slaves had no modesty or sexual honour (Walters 1997:29-46). This was especially important for slave women. In his Adversus Judaeos 2,7 Chrysostom describes the punishment of a licentious slave girl:

And when a noble and free man has an incontinent slave woman, who lures in all the bystanders for licentious purposes, he does not allow her to go out into the street, or to be seen in the alley, or to burst into the marketplace; rather, he confines her to the house, and binding her with fetters, he commands her to stay inside permanently, so that the restriction of the place and the constraint of the chains will be her starting point for modesty.

6 Translation: Garnsey (1996:93).

7 This section is from a recently discovered section of Chrysostom's homily Adversus Judaeos 2.124ra; cf. Pradels et al. (2001:22-49). 
Punishment always had to have an aim, namely teaching the slave principles of Christian virtue. In terms of these outcomes, Christian ideas of the punishment of slaves differed little from the traditional Roman perspective (Bradley 1994:141-152) - despite an educational and transformative purpose (which was also present in traditional Roman thought of slave punishment), punishment remained violent and oppressive. But punishing slaves also fashioned the social honour of the slaveholder. Chrysostom is very aware of this fact. Bad slaves dishonour their masters. Chrysostom (Hom. Heb. 24.7 [Field 7.274-275]) writes:

For if we refuse to be called the masters of our bad slaves, and give up on them ... and if any one comes to us and says, "so-and-so does countless evils, he is your slave, is he not?", we immediately say, "certainly not!"

Chrysostom then explains this behaviour:

[I]n order to spare us the shame, for a slave has a close relationship with his master, and the disgrace passes from the one to the other.

The honour or shame of a slave reflected back onto the owner. It was thus important for slaveholders to master their slaves so as to make their character honourable (cf. De Wet 2008:1-13; 2010a:317-332). Punishment was a means to protect and shape the honour and, hence, masculinity of the owner (cf. also Klein 1999:356-393; Dossey 2008:3-40).

Finally, punishing the disobedient slave becomes an imitation of divine behaviour. As noted earlier, slavery was linked to sin and divine punishment. God is both a God of mercy, but also one who punishes unrighteousness. In his famous Epistula 22.30 (CSEL 54.189-191), Jerome tells the recipient of the letter, Eustochium, about a dream he had while he was gravely ill. In Jerome's dream, he appears before the throne of God, who rebukes Jerome for his love of Latin classical literature, particularly the works of Cicero. God says to Jerome that he is not a Christian, but a Ciceronian. After this accusation, God orders that Jerome be scourged like a slave. One must remember that the metaphor of the Christian as a slave of God was extremely popular in the literature of the early church. Jerome is whipped like a disobedient slave of God - and he repents. After this dream, as Jerome tells us, he had bruises on his back and shoulders from the divine whipping. However, he was quickly restored to health, and changed his behaviour to (apparently) shun all non-Christian works on literature.

Jerome, the unjust slave, is rightly punished for his bad behaviour. God takes up the role of both the angry judge and the powerful and just master, 
who punishes when there is need. ${ }^{8}$ The aim of the punishment is to change Jerome's behaviour, just like punishment of earthly slaves had to better their own conduct. Furthermore, Jerome tells the virgin Eustochium about this event in order that she may behave in the same way, namely to place the writings of the Bible above all others. Eustochium, then, who is also a slave of God, is motivated by this spectacle of Jerome's punishment to also exhibit proper and fitting conduct (Klein 2001:401-425). Most importantly, punishment was a key method for instilling habits of obedience into slaves (Glancy 2010a:63-80).

\section{HOW TO PUNISH SLAVES}

As noted earlier, many of the writers of the early church at some point approved of some of the harshest methods of punishment. Methods of punishment included deprivation of food and drink, house arrest, sale, binding with chains, and, of course, whipping. In the case of murder, the guilty slave(s) as well as other domestic slaves were executed.

Above all, whipping is considered the typical punishment for unruly slaves. As in his dream, Jerome even considered God as a master who whips his slaves. Cyprian (Demetr. 8-9 [PL 4.549-550]) had a similar view. Scars resulting from whipping were the defining marks of the slave body, and were symbols of social disgrace. Glancy (2010b:30) states that whipping "played a pedagogic and ultimately epistemological function, imparting knowledge of degradation and dishonorable submissiveness", while Harper (2011:228) correctly notes that "[f]logging was a physical and psychological punishment; the whip was the icon of mastery". ${ }^{9}$ Whipping was often done in public, especially so that other slaves may witness it, thus serving as a deterrent for possible bad behaviour. Chrysostom (Laz. 3.7 [PG 48.1003.42-43]) states that "[s]courging one slave, often makes the rest more disciplined out of fear". He also indicates that an intense lashing included thirty and fifty blows (Adv. Jud. 8.6.7-8.6.8 [PG 48.936.56-937.4]).

Although the majority of the Church Fathers believed that whipping was acceptable under certain circumstances, there is also an aversion to the excessive violence of whipping. Although he does not directly criticise masters for whipping their slaves, Cyprian (Demetr. 8-9 [PL 4.549-550]) does note that masters often whip their slaves in order to extract the service they

8 In Jerome's dream, the metaphors of the court interrogation and the whipping of a bad slave overlap.

9 For more on the relation between the physical and psychological aspects of punishment, cf. Patterson (1982:3-5). 
require, while they themselves do not submit to God, and hence also suffer under God's whip. Cyprian (Demetr. 8-9 [PL 4.549-550]) laments:

From your slave you yourself demand service; and although you are a human being, you compel your fellow-human to submit, and to be obedient to you; and although you share the same fate in respect of being born, and the same condition in respect of dying; although you have the same bodily substance and a common arrangement of souls, and although you come into this world of ours and depart from it after a time with equal rights, and by the same law; yet, unless you are served by him according to your pleasure, unless you are obeyed by him in conformity to your will, you, as an imperious and excessive exactor of his service, flog and scourge him: you afflict and torture him with hunger, with thirst and nakedness, and even frequently with the sword and with imprisonment. And, wretch that you are, do you not acknowledge the Lord your God while you yourself are thus exercising lordship? And therefore with reason, in these plagues that occur, they do not want God's stripes and scourges. ${ }^{10}$

Glancy (2011:473) states in this regard: "Beyond an implicit critique of slaveholders who wielded excessive force against their slaves, Cyprian sketched no practical consequences from his strongly worded statement of equality." However, in this passage, Cyprian is utilising a very common Stoic trope, one also found in the New Testament, namely the shared origins of masters and slaves. Similarly, Aphrahat (Dem. 22.7 [PS 1.1008]) warns his readers:

He [death] leads away to himself both slaves together with their masters; and there the masters are not honoured more than their slaves. Small and great are there, and they hear not the voice of the oppressor. The slave who is freed from his master there pays no regard to him who used to oppress him (cf. Job 3:18-3.19). ${ }^{11}$

The idea that slaves and masters had a shared humanity derives from ancient Stoic thought, which was transferred into early Christian thought via the pseudo-Pauline Haustafeln, in which it is stated that masters ought to treat slaves fairly, since they share the same heavenly slaveholder (cf. Eph. 6:9 and Col. 4:1; see also Harrill 2005:85-118). Thus, slaveholders had to punish their slaves with the thought that they too were slaves of God and subject to God's mercy and punishment. Fitzgerald (2010:154-162) convincingly illustrated how indebted the early Christians were to the Stoics in their views on the treatment of slaves, especially regarding

10 Translation: NPNF (slightly modified).

11 Translation: NPNF (slightly modified). 
punishment. In his famous Epistula 47.10-12 (LCL 306-308), which deals directly with slavery, Seneca tells slaveholders the following:

Kindly remember that he whom you call your slave sprang from the same stock, is smiled upon by the same skies, and on equal terms with yourself breathes, lives, and dies. It is just as possible for you to see in him a free-born man as for him to see in you a slave ... I do not wish to involve myself in too large a question, and to discuss the treatment of slaves, towards whom we Romans are excessively haughty, cruel, and insulting. But this is the kernel of my advice: Treat your inferiors as you would be treated by your betters. And as often as you reflect how much power you have over a slave, remember that your master has just as much power over you. "But I have no master," you say. You are still young; perhaps you will have one. ${ }^{12}$

Seneca's words are remarkably similar to those of Cyprian. Slaveholders need to remember that they "sprang from the same stock" or seed, and share the same pre-existential origin (cf. McKeown 2007:265-279; Bradley 1986:161-172). ${ }^{13}$ Related arguments are found in Epictetus (Diss. 1.13.3-4 [LCL 100-101]) and Cicero (Leg. 1.24 [LCL 340-343]), who both emphasise that all human beings are, in fact, divine offspring regardless of their earthly social status. The Church Father Ambrosiaster (Comm. Eph. 6.9 [CSEL 81.3.120]) goes so far as to state that masters will be judged by the same measure they used on their earthly slaves:

\begin{abstract}
Earthly masters should realise that God is the common Master of all people, and therefore they should only demand such service [from their slaves] as they would be prepared to render if it were asked of them. In this sense, the measure they give is the measure they will receive. The Lord is a fair judge who gives a verdict according to the cases, not according to the status of the persons involved.
\end{abstract}

Thus, although slaveholders are allowed to punish when the situation calls for it, and even by punishing they imitate God, they also need to bear in mind that they too are slaves of God. In his reading of Paul's Epistle to Philemon, Ambrosiaster (Comm. Phlm. 16 [CSEL 81.3.340]) says of slaves and masters that "we are all of the same Adam and ought to recognise ourselves as brothers". Ambrosiaster thus interprets Paul's admonition to Philemon to accept Onesimus as a brother in a Stoic way.

12 Translation: LCL 306-308.

13 For more detailed discussions on this Stoic argument of the shared nature of masters and slaves, cf. McKeown (2007); Veyne (2003:139-143); Rocca-Serra (1976); Richter (1958). 
In one of his most eloquent admonitions, Chrysostom (Hom. Col. 12.1 [Field 5.301]) muses: "Remember Paul's bonds, and you will immediately stay your fury." Chrysostom then continues to articulate the important Christian virtue of mercy and pacifism: "Remember that we are of the bound, not the binders, of the bruised in heart, not the bruisers."14 Thus, before a master punishes a slave, he should remember that, in the history of Christianity, figures such as Paul showed more solidarity with the punished than with the punishers.

Finally, and most importantly, the Christian authors of Late Antiquity firmly believed that a master should never lose his/her temper when punishing a slave. The emotional state of the slaveholder was a major concern, especially in terms of punishment. This was a regular motif in ancient philosophy (Fitzgerald 1996:34-41). Mastering one's anger was considered more important than the act of punishing the slave. In a very telling anecdote, Plutarch (Mor. 3 [Apoph. lac.] 232c5-6 [LCL 394-395]) commended the Spartan Charillus: "[W]hen one of the Helots conducted himself rather boldly toward him, he said, 'If I were not angry, I would kill you."'15 A master should not lose control of his anger; neither should he show mercy too soon, nor display too much leniency. The control of anger is, therefore, very specific - anger is not evil in itself - and there is also righteous anger. In his exposition on the anger of God (Ir. 17.11 [SC 289.176]), Lactantius explains how proper anger should function in terms of the punishment of slaves:

I would gladly ask from those who represent God as immoveable, if anyone had property, a house, a household of slaves, and his slaves, despising the forbearance of their master, should attack all things, and themselves take the enjoyment of his goods, if his household should honour them, while the master was despised by all, insulted, and deserted: could he be a wise man who should not avenge the insults, but permit those over whom he had power to have the enjoyment of his property? Can such forbearance be found in anyone? If, indeed, it is to be called forbearance, and not rather a kind of insensible stupor. But it is easy to endure contempt. What if those things were done which are spoken of by Cicero? For I ask, if any head of a family, when his children had been put to death by a slave, his wife slain and his house set on fire, should not exact most severe punishment from that slave, whether he would appear to be kind and merciful, or inhuman and most cruel? But if to pardon deeds of this kind is the part of cruelty rather than of kindness, it is

14 Translation: NPNF (this successfully captures Chrysostom's beautiful prose).

15 Translation: LCL 394-395. Cf. also Seneca, Ira 2.26.6, 3.4.4. For more on anger in the works of Plutarch, cf. Van Hoof (2007:59-86). 
not therefore the part of goodness in God not to be moved at those things which are done unjustly. For the world is, as it were, the house of God, and humanity, as it were, His slaves; and if His name is a mockery to them, what kind or amount of forbearance is it to give up His own honours, to see wicked and unjust things done, and not to be indignant, which is peculiar and natural to Him who is displeased with sins! To become angry, therefore, is the part of reason: for thus faults are removed, and licentiousness is curbed; and this is plainly in accordance with justice and wisdom. ${ }^{16}$

Lactantius is very precise in his explanation of just anger. It is something that is to be controlled by reason and applied in specific circumstances justly and with wisdom. In this instance, one notes that God is compared to the slaveholder who knows how to control his anger, and dispense punishment fairly and justly. Punishment should, therefore, never be accompanied by excessive anger and violence. Chrysostom (Inan. 73.891-893 [SC 188.174]) tells fathers to teach their young sons to control their anger by guiding them on how and when to punish their slaves, telling us that children, especially males, were probably involved in the punishment of slaves from a very young age. Fathers must say to their sons: "If you see that your slave has broken one of your pencils or damaged a pen, do not be angry or insulting but forgiving and gentle." Chrysostom (Inan. 73.895-898 [SC 188.176]) then describes how some children treated their slaves: "[C]hildren become cantankerous when such items are damaged and tend rather to lose their soul than to let the offender go unpunished" (cf. also De Wet 2015:218). Some Church Fathers' critique of excessive violence and abusive slaveholders seems to follow the Stoic trope that slave rebellions are the result of abusive masters (cf. Harrill 1998:97; Bradley 1989).

\section{THE FEAR AND PAIN OF PUNISHMENT}

Fear was viewed as the most prevalent and important element in the punishment of slaves. The mere possibility of punishment, or the sight of someone else being punished, inspired fear. In Roman thought, slaves had to be dominated by fear. The same was true for children, who had to fear their parents, and, more generally, believers who had to fear God. Augustine (Tract. Ev. Jo. 43.7 [CCSL 36.375]) discerned two different types of fear, one that is good and righteous, and the other that is characteristic of a slavish disposition:

There is a slavish fear, and there is a chaste fear; there is the fear of suffering punishment, and there is another fear of losing righteousness.

16 Translation: NPNF. 
That fear of suffering punishment is slavish. Is it then remarkable to fear punishment? The most wicked slave and the cruellest robber fear in this manner. It is no remarkable feat to fear punishment, but it is exceptional to love righteousness. Has the person, then, who loves righteousness, no fear? Certainly such a person has fear, but not of incurring of punishment, but of losing righteousness.

Augustine explains the complexity of fear, and its different manifestations. The fear of punishment is the epitome of a slavish character. The fear that believers ought to have for God, despite themselves being slaves of God, should not be a fear of punishment, but a fear of not being righteous. Chrysostom (Hom. I Tim. 16.2 [Field 6.141]), however, did use the fear that obedient slaves have for their masters as an example of how Christians should fear God: "But I especially encourage you to imitate slaves; only in that they work out of fear of their masters, let us do the same out of the fear of God." Finally, fear makes slaves not only more obedient to the master, but also more obedient to God, as Ambrosiaster (Comm. Col. 3.23-25 [CSEL 81.3.201-202]) explains: "Paul wants them to obey their masters as if the master were the Lord from whom they are waiting for their reward, or punishment if they have done wrong."

A further element in the punishment of slaves is pain. It is the fear of pain that actually motivates slaves to good behaviour and to work harder. In the case of whipping, not the amount of lashes, but rather the degree of pain stood out, as Chrysostom (Compunct. Stel. 2.4 [PG 47.417.20-24]) notes:

\begin{abstract}
Accordingly, after inflicting countless lashings upon some of the domestic slaves, they might hold fast saying that they certainly did not commit an offense, and because the pain which results from the lashings proves to be unbearable, they decide to stay the rest of the blows (cf. also De Wet 2015:314-315).
\end{abstract}

Pain was a central aspect of the punishment of slaves. The English word "pain" is derived from the Latin poena, which means punishment. Pain must be considered a narrative, it tells a story, and is also a story in itself. Scarry (1987) delineates two functions of pain, namely "unmaking" and "making" one's reality. I noted the following in a previous instance (De Wet 2015:314):

The piercing pain of whipping, as Chrysostom describes it here [in Compunct. Stel. 2.4], was therefore not like ponos or lypē, the honourable pains a man had to endure in war or the labour pains of women; the pain of whipping had one sole purpose - to coerce the slave body into submission and/or to shame and destroy it - the pain 
of whipping and the torture of slaves was an unmaking of the slave's body and world.

Finally, the other common theme is that after anger and punishment, love needs to be shown. Chrysostom (Serm. Gen. 3.2 [SC 433.214-217]), for instance, tells us that a good master will punish his slave, and thereafter apply ointment to the wounds. Love should be the ointment that soothes the pain of punishment.

\section{CONCLUSION}

This study indicated that the principle of the punishment of slaves was very closely interwoven with the theological convictions of the various Church Fathers whose writings were examined. The link between slavery and sin justified the punishment of slaves - slavery was also considered in itself a form of punishment for sin. Early Christian authors such as Augustine, Chrysostom, and Ambrosiaster linked slavery and sin to the events of the Garden of Eden as well as to the disobedience of Ham towards Noah. In this way, the punishment of slaves was justified, because God also punishes his own slaves. The purpose of punishment was to encourage good behaviour and better work, although it was also important that slaves behave in a manner that was pleasing to God. In terms of the method of punishment, the majority of Church Fathers, at some point, approved of the most common measures of violent punishment, including whipping, deprivation of food, and confinement. More important, however, was the slaveholder's ability to control his/her anger, and bestow punishment justly and without excessive violence. This being said, slaveholders were also reminded that they too were slaves of God, and should also examine their own faults and disobedience before meting out punishment.

The findings from this analysis again illustrate how pervasive the discourse of slavery was in early Christian theological discourse. Slavery informed some of the most basic understandings of Christian doctrine and ethics. In the minds of the Church Fathers, the reward and punishment of slaves mirrored God's own daily dealings with his people. In this sense, the early Church Fathers did not escape the culture of violence that defined the Roman world. Rather, they accepted and proliferated violence, but also transformed it and used it to fashion their theology and ethics. Modern theologians face the challenge of problematising the current oppressive metaphors of slavery so prevalent in theology and in Christian religious language. What should one do with these metaphors and discourses in the present day, and with what other metaphors and discourses can they be replaced? 


\section{BIBLIOGRAPHY}

Ambler, W.

1987. Aristotle on nature and politics: The case of slavery. Political Theory 15(3):390-410. http://dx.doi.org/10.1177/0090591787015003007

Ambrosiaster

Commentarius in Epistulam ad Colosenses. In: H. J. Vogels (ed.), Ambrosiastri qui dicitur commentarius in epistulas Paulinas, Pars III. Vienna: Hoelder-PichlerTempsky, 1969. CSEL 81.

Commentarius in Epistulam ad Ephesios. In: H. J. Vogels (ed.), Ambrosiastri qui dicitur commentarius in epistulas Paulinas, Pars III. Vienna: Hoelder-PichlerTempsky, 1969. CSEL 81.

Commentarius in Epistulam ad Filemonem. In: H. J. Vogels (ed.), Ambrosiastri qui dicitur commentarius in epistulas Paulinas, Pars III. Vienna: Hoelder-PichlerTempsky, 1969. CSEL 81.

ApHRAHAT

Demonstrationes. In: R. Graffin, et al. (eds.), PS 1.1-747.

Augustine

Enarrationes in Psalmos. In: E. Dekkers \& J. Fraipont (eds.), Augustinus: Enarrationes in Psalmos Cl-CL. Turnhout: Brepols, 1956. CCSL 40.

De civitate Dei. In: B. Dombart \& A. Kalb (eds.), Augustinus: De civitate Dei: Libri I-X. Turnhout: Brepols, 1955. CCSL 48.

In Evangelium Johannis tractatus. In: R. Willems (ed.), Augustinus: In Iohannis evangelium tractatus CXXIV. Turnhout: Brepols, 1954. CCSL 36.

Basil of Caesarea

De Spiritu Sancto. In: B. Pruche (ed.), Basile de Césarée: Sur le Saint-Esprit. Paris: Cerf, 1968. SC 17.

Bradley, K.R.

1986. Seneca and slavery. Classica et Medievalia 37:161-172.

1989. Slavery and rebellion in the Roman world, 140 B.C.-70 B.C. Bloomington, IN: Indiana University Press.

1994. Slavery and society at Rome. New York, NY: Cambridge University Press.

Clark, P.

1998. Women, slaves, and the hierarchies of domestic violence: The family of St. Augustine. In: S.R. Joshel \& S. Murnaghan (eds.), Women and slaves in GrecoRoman culture: Differential equations (New York, NY: Routledge), pp. 109-129.

Collins, B.J. ET AL. (EDS.)

2014. The SBL Handbook of Style. $2^{\text {nd }}$ ed. Atlanta, GA: SBL Press. 
CYPRIAN

Ad Demetrianum. In: J.-P. Migne (ed.), PL 4.543-64B.

DAVIS, D.B.

1988. The problem of slavery in Western culture. New York, NY: Oxford University Press.

De Wet, C.L.

2008. John Chrysostom on slavery. Studia Historiae Ecclesiasticae 34(2):1-13.

2010a. Honour discourse in John Chrysostom's exegesis of the Letter to Philemon. In: D.F. Tolmie \& A. Friedl (eds.), Philemon in perspective: Interpreting a Pauline letter (Berlin: De Gruyter), pp. 317-332. http://dx.doi. org/10.1515/9783110221749

$2010 b$. Sin as slavery and/or slavery as $\sin$ ? On the relationship between slavery and Christian hamartiology in late ancient Christianity. Religion \& Theology 17(1-2):26-39.

2015. Preaching bondage: John Chrysostom and the discourse of slavery in early Christianity. Oakland, CA: University of California Press.

DosSEY, L.

2008. Wife beating and manliness in late antiquity. Past \& Present 199:3-40. http://dx.doi.org/10.1093/pastj/gtn003

\section{EPICTETUS}

1925. Dissertationes. In: W.A. Oldfather (ed.), Epictetus: Discourses, Books 1-2. Cambridge, MA: Harvard University Press. LCL 131.

FieLD, F. (ED.)

1854-1862. Ioannis Chrysostomi interpretatio omnium epistularum Paulinarum. 7 vols. Oxford: J.H. Parker.

FITZGERALD, J.T. 2010. The Stoics and the early Christians on the treatment of slaves. In: T. Rasimus, T. Engberg-Pedersen \& I. Dunderberg (eds.), Stoicism in Early Christianity (Grand Rapids, MI: Baker Academic), pp. 154-162.

Fitzgerald, W.

1996. Slavery and the Roman literary imagination. Cambridge: Cambridge University Press.

Garnsey, P.

1996. Ideas of slavery from Aristotle to Augustine. Cambridge: Cambridge University Press.

Garver, E.

1994. Aristotle's natural slaves: Incomplete praxeis and incomplete human beings. Journal of the History of Philosophy 32(2):173-195. http://dx.doi. org/10.1353/hph.1994.0038 
GLAncY, J.A.

2006. Slavery in Early Christianity. Minneapolis, MN: Fortress.

2010a. Christian slavery in Late Antiquity. In: R. Hörmann \& G. Mackenthun (eds.), Human bondage in the cultural contact zone: Transdisciplinary perspectives on slavery and its discourses (Münster: Waxmann), pp. 63-80.

2010b. Corporal knowledge: Early Christian bodies. New York, NY: Oxford University Press.

2011. Slavery and the rise of Christianity. In: K.R. Bradley \& P. Cartledge (eds.), The Cambridge world history of slavery: Volume 1: The ancient Mediterranean world (New York, NY: Cambridge University Press), pp. 456-481.

GoldenBerg, D.M.

2003. The curse of Ham: Race and slavery in early Judaism, Christianity, and Islam. Princeton, NJ: Princeton University Press.

GrafFIN, R. (ED.)

1894. Patrologia syriaca. Volume 1. Paris: Firmin-Didot.

Gregory of NYSSA

1996. Homiliae in Ecclesiasten. In: P. Alexander (ed.), Grégoire de Nysse: Homélies sur l'Ecclésiaste (Paris: Cerf), SC 416.

HARPER, K.

2011. Slavery in the late Roman world, $A D$ 275-425. New York, NY: Cambridge University Press. http://dx.doi.org/10.1017/CBO9780511973451

HARRILL, J.A.

1998. The manumission of slaves in Early Christianity. Tübingen: Mohr Siebeck. HUTh 32.

2005. Slaves in the New Testament: Literary, social, and moral dimensions. Minneapolis, MN: Fortress Press.

2006. The metaphor of slavery in the writings of Tertullian. Studia Patristica 42:385-390.

HAYNES, S.R.

2002. Noah's curse: The Biblical justification of American slavery. New York, NY: Oxford University Press. http://dx.doi.org/10.1093/0195142799.001.0001

Heath, M.

2008. Aristotle on natural slavery. Phronesis 53:243-270. http://dx.doi. org/10.1163/156852808X307070

HILL, R.C. (TRANS.)

2004. St. John Chrysostom: Eight sermons on the Book of Genesis. Brookline, MA: Holy Cross Orthodox Press. 
JEROME

Epistulae. In: I. Hilberg (ed.), Sancti Eusebii Hieronymi Epistulae, Pars I. Vienna: Hoelder-Pichler-Tempsky, 1910. CSEL 54.

John Chrysostom

Ad Stelechium de compunctione. In: J.-P. Migne (ed.), PG 47.411-22.

Adversus Judaeos. In: J.-P Migne (ed.), PG 48.843-942.

De inani gloria et de educandis liberis. In: A.-M. Malingrey (ed.), Jean Chrysostome: Sur la vaine gloire et l'éducation des enfants. Paris: Cerf, 1972. SC 188.

De Lazaro. In: J.-P. Migne (ed.), PG 48.963-1054.

Homiliae in epistulam ad Hebraeos. In: F. Field (ed.), 7.1-384.

Homiliae in epistulam ad Philemonem. In: F. Field (ed.), 6.325-53.

Homiliae in epistulam I ad Timotheum. In: F. Field (ed.), 6.1-161.

In Genesim (sermones). In: L. Brottier (ed.), Jean Chrysostome: Sermons sur la Genèse. Paris: Cerf. 1998. SC 433.

In illud: Habentes eundem spiritum. In: J.-P. Migne (ed.), PG 51.187-208.

KLEIN, R.

1988. Die Sklaverei in der Sicht der Bischöfe Ambrosius und Augustinus. Stuttgart: Steiner.

1999. Zum Verhältnis von Herren und Sklaven in der Spätantike. In: R. VonHaeling \& K. Scherberich (eds.), Roma versa per aevum: Ausgewählte Schriften zur heidnischen und christlichen Spätantike (Hildesheim: Georg Olms), pp. 356-393.

2001. Der Kirchenvater Hieronymus und die Sklaverei: Ein Einblick. In: H. Bellen \& H. Heinen (eds.), Fünfzig Jahre Forschungen zur antiken Sklaverei an der Mainzer Akademie, 1950-2000: Miscellanea zum Jubiläum (Stuttgart: Steiner), pp. 401-425.

LACTANTIUS

De ira Dei. In: C. Ingremeau (ed.), Lactance: La colère de Dieu. Paris: Cerf, 1982. SC 289.

McKeown, N.

2007. The sound of John Henderson laughing: Pliny 3.14 and Roman slave owners' fear of their slaves. In: A. Serghidou (ed.), Fear of slaves - Fear of enslavement in the ancient Mediterranean (Besançon: Presses universitaires de Franche-Comté. Actes du XXIXe colloque international du groupe international de recherches sur l'esclavage dans l'antiquité), pp. 265-279.

Migne, J.-P. (ED.)

1844-1864. Patrologiae cursus completus: Series Latina. 217 vols. Paris.

1857-1886. Patrologiae cursus completus: Series Graeca. 162 vols. Paris. 
Patterson, O. 1982. Slavery and social death: A comparative study. Cambridge, MA: Harvard University Press.

Plutarch

Moralia. In: F.C. Babbitt (ed.), Plutarch: Moralia: Volume 3. Cambridge, MA: Harvard University Press, 1931. LCL 245.

Pradels, W., Brändle, R. \& Heimgartner, M. 2001. Das bisher vermisste Textstück in Johannes Chrysostomus, Adversus Judaeos, Oratio 2. Zeitschrift für antikes Christentum 5:22-49.

RICHTER, W. 1958. Seneca und die Sklaven. Gymnasium 65:196-218.

Rocca-SerRa, G. 1976. Le stoicisme pré-imperial et l'esclavage. CRDAC 8:205-222.

SCARRY, E. 1987. The body in pain: The making and unmaking of the world. New York, NY: Oxford University Press.

SCHAFF, P. (ED.) 1887. A select library of Nicene and post-Nicene fathers. Whitefish, MT: Kessinger. Reprint.

SeneCA

De ira. In: J.W. Basore (ed.), Seneca: Moral Essays: Volume 1. Cambridge, MA: Harvard University Press, 1928. LCL 214.

Epistulae. In: R.M. Gummere (ed.), Seneca: Epistles 1-65: Volume 4. Cambridge, MA: Harvard University Press, 1917. LCL 75.

Tertullian

Adversus Marcionem. In: E. Dekkers, J.G.P. Borleffs, R. Willems, R.F. Refoulé, G.F. Diercks, \& A. Kroymann (eds.), Tertullianus: Opera I. Turnhout: Brepols, 1954. CCSL 1.

VAN Hoof, L.

2007. Strategic differences: Seneca and Plutarch on controlling anger. Mnemosyne 60:59-86. http://dx.doi.org/10.1163/156852507X165847

Veyne, $P$.

2003. Seneca: The life of a Stoic. New York, NY: Routledge.

WALTERS, J.

1997. Invading the Roman body: Manliness and impenetrability in Roman thought. In: J.P. Hallett \& M.B. Skinner (eds.), Roman sexualities (Princeton, NJ: Princeton University Press), pp. 29-46. 
De Wet

Keywords

Slavery

Church History

Punishment

Discipline

Church Fathers

Patristics
The punishment of slaves in Early Christianity

Trefwoorde

Slawerny

Kerkgeskiedenis

Straf

Dissipline

Kerkvaders

Patristiek 